Journal of Management

Vol. 44 No. 6, July 2018 2405-2432

DOI: $10.1177 / 0149206318771177$

(C) The Author(s) 2018

Reprints and permissions:

sagepub.com/journalsPermissions.nav

\title{
CEO Wrongdoing: A Review of Pressure, Opportunity, and Rationalization
}

\author{
Karen Schnatterly \\ K. Ashley Gangloff \\ University of Missouri \\ Anja Tuschke \\ Ludwig-Maximilians-Universität München
}

\begin{abstract}
Wrongdoing, and specifically that which is committed by top executives, has attracted scholars for decades for a number of reasons. Among them, the consequences of wrongdoing are widespread for organizations and the people in and around them. Due to the vast array of consequences, there continues to be new questions and additional scholarly attempts to uncover why it occurs. In this review, we build upon previous efforts to synthesize the body of literature regarding the antecedents of $C E O$ wrongdoing utilizing a framework that sheds light on the status of the literature and where unanswered questions remain. We apply the Fraud Triangle, a framework drawn from the accounting literature, to derive conclusions about what we know about the pressures faced by CEOs, the opportunities afforded to CEOs to commit wrongdoing, and contributing factors to a CEO's ability to rationalize misbehavior. We organize the literature on these conceptual antecedents of $C E O$ wrongdoing around internal (e.g., compensation structure and organizational culture) and external (e.g., shareholder pressure and social aspirations) forces. In doing so, we integrate findings from a variety of disciplines (i.e., accounting, finance, and sociology) but remain focused on management scholarship since the last review of organizational wrongdoing to provide an updated state of the literature. This review offers a clear framework and a common language; it highlights gaps in the literature and specific directions for future research with the ultimate goal of understanding why CEOs engage in wrongdoing.
\end{abstract}

Keywords: wrongdoing; fraud; CEO; antecedents

\footnotetext{
Acknowledgments: We would like to thank Jonathan Bundy, Aaron Hill, Scott Johnson, and Margaret White for comments on earlier versions of this article.

Corresponding author: Karen Schnatterly, University of Missouri-Columbia, Cornell Hall, Columbia, MO 65211, USA.

E-mail: schnatterlyk@missouri.edu
} 
Why do organizational leaders engage in wrongdoing? Wrongdoing is behavior that a social-control agent judges to transgress a line separating right from wrong, where such a line can separate legal, ethical, and socially responsible behavior from its antithesis (Greve, Palmer, \& Pozner, 2010). Wrongdoing, specifically at the hand of the CEO, can come in many forms, and its consequences are far-reaching, resulting in a variety of negative outcomes for the executives that commit the wrongdoing, their organizations, and even other bystander stakeholders (e.g., employees). Wrongdoing's consequences are not just far-reaching but are costly to societies and firms. Recent estimates suggest that fraud, a specific type of wrongdoing, results in a loss of $5 \%$ of sales for a typical company every year and a global loss of around \$3.7 trillion (Association of Certified Fraud Examiners, 2014). Research suggests that governance and control mechanisms, such as effective boards of directors, internal systems and structures, and firm cultures that promote lawfulness, can constrain CEOs from engaging in, or facilitating others to engage in, wrongdoing (Pfarrer, Smith, Bartol, Khanin, \& Zhang, 2008; Zahra, Priem, \& Rasheed, 2005). When these mechanisms have been disrupted, they increase tendencies for law-breaking behavior of employees (Schnatterly, 2003). While there is some understanding of (un)ethical decisions and behaviors of individuals, the literature on why CEOs commit or enable wrongdoing remains disparate and incomplete. As a result, we have a piecemeal understanding of the antecedents of CEO wrongdoing and a limited ability to make recommendations to reduce the occurrence of such behavior (Daily, Dalton, \& Cannella, 2003; Dowell, Shackell, \& Stuart, 2011; Tihanyi, Graffin, \& George, 2014). If we know more about the internal and external forces that foster or allow for CEO misbehavior, we can better help organizations choose CEOs and build more effective structures and processes to encourage ethical behavior. This review brings the literature on CEO wrongdoing together and structures it in an effort to better understand these antecedents and improve our ability to offer practical recommendations.

In this review, we focus on the antecedents of wrongdoing to understand how and why CEOs engage in wrongdoing. For the purposes of this review, in all instances of the use of or reference to wrongdoing and its synonyms, we refer to the CEO's commission or facilitation of such behavior. We focus on the CEO because of his or her influence on the strategic direction of the firm as well as its culture supported by decades of upper-echelons research (M. Carpenter, Geletkanycz, \& Sanders, 2004; Finkelstein \& Hambrick, 1996; Hambrick, 2007; Hambrick \& Mason, 1984). Upper-echelons theory scholarship has evolved from the examination of the influence of CEO demographics to more "black box" cognitive variables, such as hubris (Y. Tang, Li, \& Yang, 2015) and core self-evaluation (Simsek, Heavey, \& Veiga, 2010). However, despite refinement in theory, upper-echelons theory has remained a mainstay in strategy research, ultimately concluding that CEOs "matter." Firm behaviors reflect CEOs' cognitions and values (Gupta, Briscoe, \& Hambrick, 2017; Hambrick, 2007; Hambrick $\&$ Mason, 1984). Furthermore, the activities of other organizational members are possible by way of the culture and controls overseen by the CEO. In line with these conclusions, if the firm and its strategic direction are a reflection of the CEO, so, too, is the firm's misconduct. ${ }^{1}$ Examples of direct wrongdoing at the hand of the CEO include WorldCom, Enron, and Tyco. In these cases, the CEO was directly responsible for fraudulent activity to the tune of billions of dollars, damaging a variety of internal and external stakeholders. On the other hand, in the Wells Fargo scandal, employees created millions of fake bank accounts, and while the CEO did not directly participate, his strategy of cross-selling more accounts ("eight is great") and 
incentivizing such tactics is generally considered the origin of the scandal (McGrath, 2016). Scholarship in accounting and finance places a similar focus on top executives and, specifically, the CEO (Cline, Walkling, \& Yore, 2017; Desai, Hogan, \& Wilkins, 2006; Erickson, Hanlon, \& Maydew, 2006), as does an earlier review of fraud by Zahra et al. (2005). Thus, our review concentrates on wrongdoing committed by the CEO or the commission of wrongdoing for which the CEO is otherwise responsible.

To review the literature on CEO wrongdoing, we adopt a framework common in the auditing literature: the Fraud Triangle (Cressey, 1950; Dorminey, Fleming, Kranacher, \& Riley, 2012; Trompeter, Carpenter, Desai, Jones, \& Riley, 2013); however, we extend it beyond the limitations of fraud and include a variety of forms of wrongdoing. The Fraud Triangle encompasses pressure, opportunity, and rationalization. In our assessment of the current literature, it became clear that the CEO exists not in a vacuum but within the context of his or her firm, under the supervision of the board of directors, with the watchful eyes of shareholders, and within industries as well as the greater macroeconomy (Ashforth, Gioia, Robinson, \& Trevino, 2008). Thus, we apply the Fraud Triangle in a way that allows for a comprehensive review of pressures, opportunities, and the rationalization of the CEO born from or fostered by internal (e.g., compensation, firm structure, and board monitoring) and external (e.g., industry competitors, and the media) forces.

Our review provides several contributions to the literature above and beyond a catalog of recent research. We focus on antecedents to CEO wrongdoing that derive from both internal and external factors and organize it within the Fraud Triangle. In doing so, we refine earlier reviews that identify organization, industry, and societal antecedents (e.g., Zahra et al., 2005) by decomposing studies and their conclusions based on how they give rise to CEO wrongdoing (e.g., via pressure, opportunity, or rationalization). Ultimately, our review provides a clear framework within which we assess current literature and its contribution to our understanding of how CEO wrongdoing comes to be. We apply a common language that allows for improved integration of research and identify important gaps in our understanding of CEO wrongdoing, which underscore opportunities for future research.

\section{Literature Review}

To review the literature on organizational wrongdoing associated with the CEO, we searched all articles published in major management journals, with certain limiters. Zahra et al. (2005) published a review of fraud in 2005; although fraud is not completely synonymous (i.e., fraud is one specific type of wrongdoing and is defined as "deliberate actions taken by management at any level to deceive, con, swindle, or cheat investors or other key stakeholders"; Zahra et al., 2005: 804), we take this as our starting point. ${ }^{2}$ We integrate the main findings of that review in this article to provide a comprehensive and accessible review of scholarship. We extend our search beyond fraud to wrongdoing because of the nature of and difficulty in assessing intentionality, a specific component of fraud. We are interested in studies of antecedents of wrongdoing in organizations recognizing that many studies do not use wrongdoing but rather use a synonym or a specific type of wrongdoing. As such, we searched for articles that used wrongdoing, fraud, crime, illegal, misconduct, or malfeasance in the abstract. Following Short (2009), we included all articles from Academy of Management Journal (AMJ), Academy of Management Review (AMR), Administrative Science Quarterly (ASQ), Journal of Management (JOM), 
Journal of Management Studies (JMS), Organization Science (OS), and the Strategic Management Journal (SMJ). Additionally, we included articles published in the Journal of Business Ethics (JBE), Management Science (MS), and Strategic Organization (SO) to broaden our search. Further, we searched the references of the relevant articles as well as the articles that cite these articles (following S. G. Johnson, Schnatterly, \& Hill, 2013). We eliminated articles from the review for the following reasons: They did not relate to the CEO, directly or indirectly; they did not focus on antecedents of wrongdoing in their hypotheses or propositions; or they focused on wrongdoing in countries outside of the United States. We are interested in research where the CEO is a primary focus and that focuses on antecedents of wrongdoing. We also focus on U.S. samples in order to control for the institutional environment, as these additional issues are beyond the scope of this review. We address some of the international or comparative international literature on wrongdoing (e.g., corruption) in the Future Research section. After reviewing the scope of this literature, we chose to focus on all the forms of wrongdoing as a construct but note that the majority of this literature reflects financial misstatements. All together, we found 54 articles that met our search criteria. These articles are marked with an asterisk in the References section. In addition to our search within the management discipline, we integrate relevant accounting, finance, and sociology literature to supplement the work of management scholars.

\section{Wrongdoing}

\section{Defining Wrongdoing}

Scholars define, classify, and measure organizational wrongdoing in numerous ways (Pinto, Leana, \& Pil, 2008; Vadera, \& Pratt, 2013). We adapt the definition put forth by Greve et al. (2010) and define wrongdoing as behavior that a social-control agent judges to transgress a line separating right from wrong, where such a line can separate legal, ethical, and socially responsible behavior from its antithesis. Our adaptation removes in or by organizations because of our focus on the CEO as the primary actor. While some scholars focus on specific types of wrongdoing in their exploration and scholarship (e.g., Amiram, Bozanic, Cox, Dupont, Karpoff, \& Sloan, in press; Zahra et al., 2005), we choose to use this definition because wrongdoing has a scope that can include a variety of misbehaviors. For our review, wrongdoing spans activities such as asset misappropriation (i.e., theft, embezzlement, or inappropriate use of company resources, and can include cash or other assets), market manipulation, fraud ("deliberate actions taken by management at any level to deceive, con, swindle, or cheat investors and other key stakeholders,"3 Zahra et al., 2005: 804), and other illegal activities. It also includes some activities that fall in legal gray areas or are, in fact, legal but generally seen as "wrong" rather than "right" (e.g., earnings management or lying).

Empirical papers often analyze one specific type of wrongdoing to draw generalizable conclusions about wrongdoing and its antecedents. Previous research has measured wrongdoing as product recalls (Zavyalova, Pfarrer, Reger, \& Shapiro, 2012), retaliation (Rehg, Miceli, Near, \& Van Scotter, 2008), and unethical decision making (Stevens, Deuling, \& Armenakis, 2012) to name a few. However, the most prominent measure of wrongdoing used among management scholars is financial misconduct as reflected in financial misreporting (Amiram et al., in press; Chen, 2010; O'Connor, Priem, Coombs, \& Gilley, 2006; Troy, Smith, \& Domino, 2011). More specifically, in the past two decades, scholars have used financial restatement as 
a dependent variable to explore wrongdoing more than any other proxy (Harris \& Bromiley, 2007; Ndofor, Wesley, \& Priem, 2015; Peterburgsky, 2012). Combined, these actions represent a more complete sample of acts of wrongdoing than fraud.

The measurement, beyond type, of wrongdoing is also noteworthy. The majority of empirical investigations measures wrongdoing as a binary variable (O'Connor et al., 2006, Shi, Connelly, \& Sanders, 2016; Troy et al., 2011) along the lines of "committed the wrong" versus "did not commit the wrong." Scholars utilize extensive databases, such as the Government Accountability Office reports (e.g., Ndofor et al., 2015) to gather information about the occurrence of wrongdoing. While widely accepted, some scholars warn against the imperfections of such databases (Karpoff, Koester, Lee, \& Martin, 2017). Only some scholars explore the magnitude of wrongdoing, and those that do often use wrongdoing as an independent variable on some other dependent variable (e.g., whistle-blowing; Vadera, Aguilera, \& Caza, 2009). The literature also includes studies that utilize surveys, in which the dependent variable is related to wrongdoing (e.g., deception or unethical decision making; Smith-Crowe, Tenbrunsel, Chan-Serafin, Brief, Umphress, \& Joseph, 2015; Stevens et al., 2012), and content analysis to explore wrongdoing in a broader sense of the concept (e.g., the language of white-collar crime; Vadera \& Aguilera, 2015). Although we focus on wrongdoing antecedents in this review, event studies, which capture the market's reaction to an event (e.g., consequences of wrongdoing), are a mainstay in this line of research and worth mentioning here. Likewise, scholars have also conducted experiments in which wrongdoing is often an independent variable (e.g., Dalton \& Radtke, 2013). Table 1 summarizes measures of wrongdoing used in the management literature.

\section{Review Framework}

\section{Applying the Fraud Triangle}

The Fraud Triangle (Cressey, 1950, 1953), also referred to as the opportunity-motivationjustification model of crime (Aguilera \& Vadera, 2008; Albrecht, Howe, \& Romney, 1984; Coleman, 1985), provides a framework to review and organize the current literature on CEO wrongdoing. Scholars use the Fraud Triangle as a conceptual model to understand the antecedents of fraud (Dorminey et al., 2012). Auditors also use this framework; when making fraud risk assessments, auditors assess whether management has the incentive (or pressure), the opportunity, and the attitude (i.e., predisposition to rationalize) to commit fraud (Dorminey et al., 2012). The Association of Certified Fraud Examiners, the American Institute of Certified Public Accountants, and virtually every auditing textbook addresses the Fraud Triangle (Dorminey et al., 2012). The Fraud Triangle is both practical and theoretically sound. While the Fraud Triangle was originally designed for and utilized in accounting, we utilize this framework to highlight common antecedents of all forms of wrongdoing and to provide a common language to describe them. Pressure reflects the necessity to commit wrongdoing ("have to"). Opportunity suggests the ability to commit wrongdoing with the expectation that it will not be detected or punished ("can"; Dorminey et al., 2012). Finally, rationalization is the ability to explain an act of wrongdoing as morally justifiable ("it's okay"). Inherently different from the imposed pressure or observable opportunity, rationalizations are "mental strategies that allow [individuals] to view their corrupt acts as justified" (Anand, Ashforth, \& Joshi, 2004: 39). They are unobservable but facilitate wrongdoing. 


\section{Table 1}

\section{Type and Measure of Wrongdoing}

\begin{tabular}{lcc}
\hline Measure & $\begin{array}{c}\text { Variable Description and Source } \\
\text { (where applicable) }\end{array}$ & Key References \\
\hline
\end{tabular}

Accounting/financial

reporting fraud

Restatements: GAO

Binary variable. Voluntary restatement of firm financial earnings for a specific year in a GAO report.

Restatements: AAERs Binary variable. Company fraud-years.

Restatements Binary variable. Restatements reported in the news and found through a LexisNexis search for restat* or revis*.

SEC/DOJ investigations Binary or count variable. Investigations supplied by the Corporate Fraud Task Force and supplemented with SEC selected AAERs.

Securities class action lawsuits

Binary or count variable. Lawsuit information

Harris \& Bromiley, 2007; Pfarrer, Smith, Bartol, Khanin, \& Zhang, 2008

Cecchini, Aytug, Koehler, \& Pathak, 2010

Agrawal \& Chadha, 2005; Donoher, Reed, \& Storrud-Barnes, 2007; Ndofor, Wesley, \& Priem, 2015; O'Connor, Priem, Coombs, \& Gilley, 2006

Carberry \& King, 2012; Troy, Smith, \& Domino, 2011 from the Institutional Shareholder Services Securities Class Action Services and Securities Class Action Clearinghouse.

Stock option backdating Binary. Options granted on an "extremely lucky date."

Detected fraud cases/ Binary variable. Cases identified in the China firm fraud commitment Securities Regulatory Commission data.

Cumulative abnormal

Continuous variable. Sum of abnormal daily returns returns by firm calculated as the discrepancy between the actual return of a firm's stock and its expected return on the same day.

Illegal loan recovery

Count variable. Number of harassment complaints against the firm from Banking Ombudsman's annual reports.

Stock option expensing (SOPEX) adoption time

Count variable. Number of months from a

Bianchi \& Mohliver, 2016; Lie, 2005

Cumming, Leung, \& Rui, 2015; Yiu, Xu, \& Wan, 2014

Combs, Ketchen, Perryman, \&

Donahue, 2007; Hopkins, Maydew, \& Venkatachalam, 2014; Kang, 2008; Paruchuri \& Misangyi, 2015

Krishnan \& Kozhikode, 2015

Carberry \& King, 2012 date that a company adopted SOPEX based on firm-audited financial accounting records filed with the SEC.

Firm wage arrears

Binary and continuous variable. Wage arrears and the amount of wage arrears as reported on a survey by firm management.

Inspection leniency Binary variable. Passing score on emissions test from a state department of motor vehicles or environmental conservation data.

Trade secret protection Continuous variable. Score on an 18-item procedures

scale about handling proprietary, sensitive, and confidential information.

Litigation

Binary variable. Information on different types of litigation against the firm available from the National Archive of Criminal Justice Data.

Earle, Spicer, \& Peter, 2010

Gino \& Pierce, 2010; Pierce \& Snyder, 2008; Pierce \& Toffel, 2013

Hannah, 2005

Hutton, Jiang, \& Kumar, 2015 
Table 1 (continued)

\begin{tabular}{|c|c|c|}
\hline Measure & $\begin{array}{l}\text { Variable Description and Source } \\
\text { (where applicable) }\end{array}$ & Key References \\
\hline Corporate illegality & $\begin{array}{l}\text { Binary variable. Involvement in illegal } \\
\text { incident as reported in news. }\end{array}$ & $\begin{array}{l}\text { Mishina, Dykes, Block, \& Pollock, } \\
2010\end{array}$ \\
\hline General wrongdoing & $\begin{array}{l}\text { Continuous variable. Observed or direct } \\
\text { evidence that someone in the firm } \\
\text { committed any of } 17 \text { different acts of } \\
\text { wrongdoing captured via survey. }\end{array}$ & $\begin{array}{l}\text { Rehg, Miceli, Near, \& Van Scotter, } \\
2008\end{array}$ \\
\hline \multicolumn{3}{|l|}{ Unethical decision making } \\
\hline $\begin{array}{l}\text { Awareness of ethics- } \\
\text { related issues }\end{array}$ & $\begin{array}{l}\text { Binary variable. Identification of ethical } \\
\text { issues in making a particular decision } \\
\text { captured via survey. }\end{array}$ & Welsh \& Ordóñez, 2014 \\
\hline Unethical behavior scale & $\begin{array}{l}\text { Continuous variable. Score on a } 37 \text {-item scale } \\
\text { developed by Kaptein (2008). }\end{array}$ & Kaptein, 2008 \\
\hline $\begin{array}{l}\text { Employee resigned } \\
\text { or fired due to a } \\
\text { wrongdoing event; } \\
\text { director departure from } \\
\text { firm }\end{array}$ & $\begin{array}{l}\text { Binary variable. Based on news stories about } \\
\text { a wrongdoing event. }\end{array}$ & $\begin{array}{l}\text { Cowen \& Marcel, 2011; Wiersema \& } \\
\text { Zhang, } 2013\end{array}$ \\
\hline Unethical behavior & $\begin{array}{l}\text { Continuous variable. Score on a } 17 \text {-item scale } \\
\text { developed by Akaah (1996) }\end{array}$ & $\begin{array}{l}\text { Mayer, Aquino, Greenbaum, \& } \\
\text { Kuenzi, } 2012\end{array}$ \\
\hline Opportunism & $\begin{array}{l}\text { Continuous variable. Score on a three-item } \\
\text { scale developed by Malhotra and Gino } \\
(2011) \text { that covers distortion of information } \\
\text { and reneging on commitments. }\end{array}$ & Malhotra \& Gino, 2011 \\
\hline Deception & $\begin{array}{l}\text { Count variable. Instances of active or passive } \\
\text { deception during a negotiation. }\end{array}$ & $\begin{array}{l}\text { Jap, Robertson, \& Hamilton, 2011; } \\
\text { Malhotra \& Gino, } 2011\end{array}$ \\
\hline Lying & $\begin{array}{l}\text { Continuous variable. Answer to a survey item } \\
\text { about whether respondents thought that } \\
\text { sending a misleading message was a lie on a } \\
\text { 7-point response scale. }\end{array}$ & Zhong, 2011 \\
\hline $\begin{array}{l}\text { Retaliation against } \\
\text { whistle-blowers }\end{array}$ & $\begin{array}{l}\text { Continuous variable. Whistle-blowers' } \\
\text { experienced retaliation captured via survey. }\end{array}$ & Rehg et al., 2008 \\
\hline Number of unethical acts & $\begin{array}{l}\text { Count variable. Number of unethical acts } \\
\text { a firm committed based on news articles } \\
\text { about the firm. }\end{array}$ & Sullivan, Haunschild, \& Page, 2007 \\
\hline $\begin{array}{l}\text { Degree of legitimacy of } \\
\text { unethical acts }\end{array}$ & $\begin{array}{l}\text { Continuous variable. Score on a survey } \\
\text { developed by Sullivan et al. (2007) asking } \\
\text { respondents how appropriate it is for a } \\
\text { firm to engage in unethical acts across } 24 \\
\text { categories. }\end{array}$ & Sullivan et al., 2007 \\
\hline
\end{tabular}

Note: AAER = Accounting and Auditing Enforcement Release; DOJ = Department of Justice; GAO = Government Accountability Office; SEC $=$ Securities and Exchange Commission.

Rationalization allows individuals who have violated standards of right and wrong to continue to see themselves as competent, moral, and consistent; actions that go against these can be "rationalized away" (Anand et al., 2004; Troy et al., 2011; Zyglidopoulos, Fleming, \& Rothernberg, 2009). The extent to which the wrong is acceptable for some reason- "we will misstate our inventories this quarter and fix it next quarter" or "we won't get this deal if we don't inflate some of these numbers"-makes the act justifiable. Just before the act, the CEO convinces himself or herself that the act will not compromise his or her identity as an honest 
and ethical person, making the wrong morally acceptable (Morales, Gendron, \& GuéninParacini, 2014). Rationalization is also possible if "everyone is doing it." While pressure is applied to the CEO, and opportunity is afforded to the CEO, rationalization is inherent to the $\mathrm{CEO}$; thus we tap into the microfoundations of CEO wrongdoing to describe rationalization through the current literature but also organize scholarship regarding forces that are external to the individual that enable rationalization.

The three elements of the Fraud Triangle operate together. If all are present, wrongdoing is more likely to occur (Dorminey et al., 2012). If one is present, wrongdoing is perhaps likely but not as likely. Note that in many studies we review, scholars include measures (usually in the controls section) for more than one factor of the Fraud Triangle. In this review, we classify studies of CEO wrongdoing by the Fraud Triangle factor most relevant or significant to the study in question. We discuss overlaps as they occur and hold interactions and within and between factors until the Future Research section.

\section{Pressure}

\section{Internal Forces That Impose Pressure}

Internal forces that apply pressure to the CEO include compensation structure and firm performance as well as pressure exerted by the board of directors. Compensation structure can drive the CEO to misbehavior because of the pressure it applies (S. A. Johnson, Ryan, \& Tian, 2009; Shi et al., 2016). This constitutes a pressure brought about by greed. This literature argues that the CEO is incentivized to commit wrongdoing to inflate the stock price so as to increase his or her compensation. Research focuses on the role that options play in influencing CEOs' behavior. Scholarship consistently finds that options are associated with a greater likelihood of fraudulent financial reporting (Burns \& Kedia, 2006; Donoher, Reed, \& Storrud-Barnes, 2007; Harris \& Bromiley, 2007; O’Connor et al., 2006; Zhang, Bartol, Smith, Pfarrer, \& Khanin, 2008). Wowak, Mannor, and Wowak (2015) find that stock options are even related to product safety problems. Relatedly, finance scholarship provides evidence that executives of firms likely to have deliberately adopted aggressive accounting practices that increase the stock price of the firm exercise significantly more options (Burns \& Kedia, 2008). However, other scholars find that some stock options, especially in a loss context, induce less risk-taking behavior, highlighting the importance of "decision-relevant factors" (Sawers, Wright, \& Zamora, 2011). According to these authors, this research moves beyond agency theory and supports a behavioral agency model wherein problem framing and risk bearing in combination impact risk-taking behavior. Beyond absolute values of compensation, Shi et al. (2016) uncover evidence to support that relative levels of compensation also influence wrongdoing, where an increase in the vertical pay gap results in a greater likelihood of securities lawsuits.

Organizational characteristics can increase pressure such that the CEO believes that he or she must engage in wrongdoing. Even "good" firms facilitate bad behavior due to pressure stemming from firm performance. Both Harris and Bromiley (2007) and Mishina, Dykes, Block, and Pollock (2010) find that high-performing firms engage in misconduct. Firm performance, according to Chen (2010), also has the ability to impact CEO confidence and, in turn, increases the "need" to misreport performance as more positive than it really was to "feed an ever increasing ego" (p. 47). 
The board monitors and can fire the CEO; thus it is clear that the board can also exert pressure on the CEO. The process of "settling up"-where directors either lose or do not receive future board seats because of poor performance as a director (Fama, 1980; Wiesenfeld, Wurthmann, \& Hambrick, 2008) - is a threat to a director's reputation as well as future income. Thus, firm performance issues leave directors few options, and as a result, it is likely that the board will exert pressure on the CEO to meet announced earnings estimates or to keep improving past performance. Though some scholarship has begun to explore director compensation and strategic risk taking (Deutsch, Keil, \& Laamanen, 2011; Lim \& McCann, 2013), the link between such compensation and how that influences the board to pressure the CEO has not yet been made.

\section{External Forces That Impose Pressure}

Pressure to engage in wrongdoing can originate from forces outside of the firm, such as competition and active investors. Zahra et al. (2005) highlight theoretical explanations for the influence of competition and relative performance on wrongdoing (see anomie and strain theories; Merton, 1938); recent literature continues to explore such concepts. For example, firms facing competition for customers are associated with greater willingness to use corrupt and unethical practices (Bennett, Pierce, Snyder, \& Toffel, 2013); there is pressure on the CEO to engage in wrongdoing to retain customers. Relatedly, a firm's relative performance can create pressure on the $\mathrm{CEO}$ to engage in wrongdoing; poor performance relative to peers is associated with misbehavior (Harris \& Bromiley, 2007). Mishina et al. (2010) find similar support and extend our understanding of social aspirations and wrongdoing. Interestingly, these authors find that pressures to meet or exceed the expectations of shareholders can lead to misbehavior but only among prominent firms. The pressure created by the social environment (i.e., strain) is consistent with "pressure-driven fraud" according to Trompeter et al. (2013). Langton and Piquero (2007) also provide evidence to support that strain can predict a select group of white-collar offenses. This is consistent with conclusions drawn from evidence that executives respond differently to market-based performance problems and increasing expectations than they do to accounting-based performance problems (Donoher et al., 2007). Unfortunately, there are significant feedback loops between firm performance and pressure (Chen, 2010): The better the firm performs, the more the shareholders expect, and the more pressure the $\mathrm{CEO}$ has to deliver appealing results.

Scholars have shown that investors influence wrongdoing. For instance, shareholder proposals are positively related to earnings management, suggesting that executives respond to pressure to signal their managerial capabilities via earnings management (Hadani, Goranova, \& Khan, 2011). Shi, Connelly, and Hoskisson (2017) also find that pressure from activist owners increases the likelihood of financial wrongdoing. These authors explain that "subject to unrelenting external expectations from dedicated institutional investors and activists, [managers] may feel compelled to make financial reporting decisions not from their own beliefs, but merely to satisfy the expectations of the firm's owners" (Shi et al., 2017: 1272). Finance scholarship also concludes that ownership pressure increases the likelihood of committing wrongdoing (Denis, Hanouna, \& Sarin 2006). However, takeover defense provisions that protect top managers (e.g., golden parachutes and poison pills) can reduce such external pressures; for a firm, the number of takeover defense provisions is negatively associated with the likelihood of fraud (Shi et al., 2017). Research also nods to the pressure imposed by 
security analysts. In fact, such analyst pressure can come by way of either "sell" or "buy" recommendations. It is only a "hold" recommendation that applies the least amount of pressure via attention to performance (Shi et al., 2017).

\section{Opportunity}

\section{Internal Forces That Provide Opportunity}

The CEO's ability to commit wrongdoing depends on his or her opportunity, which can be a reflection of individual power, firm resources, firm structure and controls, or board monitoring. The more power the CEO has, the more opportunity to misbehave by overruling the board or ignoring organizational controls. A CEO's power can come from his or her role in the organizational structure (e.g., duality), a sizable ownership stake, or an information advantage over other stakeholders. Ramdani and van Witteloostuijn (2012) find that CEOs who have a significant ownership stake are more likely to engage in wrongdoing than their counterparts without this ownership stake. With regard to information power, in essence, the harder it is to clearly observe the CEO's behavior, the greater the CEO's opportunity to commit fraud. Ndofor et al. (2015) explain that CEOs of complex firms take advantage of that information asymmetry and are more likely to commit financial reporting fraud because of their knowledge advantage. Complexity of the firm as measured by diversification is related to misconduct (Chakrabarty, 2015; Ndofor et al., 2015). Specifically, unrelated diversification provides an opportunity for financially innovative practices (e.g., borrowing and lending between divisions) that may go undetected by external constituents with limited access to information (Chakrabarty, 2015).

Often explored as moderating effects, firms' formal and informal controls can influence the likelihood of executive misconduct. Formal controls (e.g., active audit committee monitoring) can decrease the positive effect of complexity on the likelihood of fraud (Ndofor et al., 2015). When formal internal controls are strong, that is, when the rules of the game are clear, it is harder to commit fraud (Liu, Wright, \& Wu, 2015). Thus, several scholars have explored control mechanisms that either make way for or reduce the likelihood of executive misconduct (Davis, Payne, \& McMahan, 2007; Dionne, Giuliano, \& Picard, 2009).

Informal controls, such as a firm's culture, climate, or history may also play a role in creating opportunity for the CEO to misbehave. Results from several studies support that individual behavior is influenced by the ethics in the organization. For instance, firm cultures that reflect a conscienceless financial self-interest motive for community involvement exacerbate the effect of opportunities to misbehave (Chakrabarty, 2015). Alternatively, the firm's culture can reduce the CEO's ability to commit wrongdoing when firms view themselves as "moral citizens," or of having a moral or ethical culture reflected in their interactions with other entities (Chakrabarty, 2015). These conclusions, at large, lend to the idea that a firm's culture can either inhibit or facilitate wrongdoing.

Other scholars have explored the interaction effect of formal and informal controls (e.g., Davis et al., 2007). When informal pressure to engage in misconduct is high, formal control systems are effective; when there is little informal pressure to do wrong, formal systems may be a "waste of time," emphasizing that when designing control systems, firms must account for the organizational environment (i.e., pressure; Smith-Crowe et al., 2015). In other instances, according to MacLean and Behnam (2010), some firms may decouple formal control systems from organizational processes completely to create a façade of legitimacy among external stakeholders while maintaining a culture that facilitates noncompliance or the institutionalization of misconduct. 
Organizational controls can also encourage employees to speak out about ongoing wrongdoing (i.e., whistle-blowing). Whistle-blowing describes individuals coming forward about either participating in or witnessing an act of wrongdoing. Whistle-blowing increases the possibility of detection of the wrong, thus reducing opportunity. Whistle-blowing is not simple, and organizational controls and structures can either encourage and support or discourage and disparage whistle-blowers. Generally, in environments where whistle-blowing occurs, the level of wrongdoing is reduced (Chen, 2010). However, the seriousness of the wrongdoing, personal costs associated with whistle-blowing (e.g., reprisal from others in the organization), and perceived personal responsibility for reporting the wrongdoing influence a whistle-blower's intent to report misconduct (Ayers \& Kaplan, 2005). Though individual differences affect one's intentions to report wrongdoing, strong ethical environments increase the likelihood of whistle-blowing (Dalton \& Radtke, 2013).

The collection of research focused on the opportunity to misbehave provided by the board of directors via lackluster monitoring is vast. As Zahra et al. (2005) point out, "a fundamental characteristic of modern corporations is the separation of ownership and control" (p. 812) as maintained by the board of directors. However, research suggests that the risk of subpar monitoring and, thus, greater likelihood of CEO wrongdoing is nuanced. Zahra et al. reviewed a breadth of literature on the role of the board of directors and its influence on fraud, generally concluding that weaker governance mechanisms and passive boards (e.g., fewer audit committee meetings) increase the likelihood of fraud. However, these authors also noted conflicting findings regarding the effectiveness of outsider directors. Agrawal and Chadha (2005) contribute to the conversation finding that several key governance characteristics, such as board and audit committee independence, are "essentially unrelated to the probability of a company restating its earnings" (p. 403), a result of financial misstatement.

Other tests of board characteristics since the last review of wrongdoing find significant effects on the CEO's misbehavior beyond compensation structure (e.g., stock ownership) of board members as reviewed by Zahra et al. (2005). For instance, generally, boards' level of business experience is negatively related to misconduct, as is average board tenure (Donoher et al., 2007). Boards that include an independent financial expert are negatively related to the probability of financial misconduct (Agrawal \& Chadha, 2005). Director tenure plays a role, but the results are equivocal. Directors with longer shared tenure implies the board and CEO have stronger friendship ties, and the board then will be less likely to monitor the CEO (Boivie, Bednar, Aguilera, \& Andrus, 2016; Brown, Anderson, Salas, \& Ward, 2017). Alternatively, directors with longer tenure have learned about the firm and the CEO, which is critical for their ability to ask informed questions and understand the answers. Thus, longer tenure reduces their information asymmetry, making it harder for the CEO to commit wrongdoing without detection. In short, the effect of tenure is still unclear. It appears that the CEO's opportunity for wrongdoing decreases as boards become more experienced and knowledgeable yet increases as friendships with board members develop (Boivie et al., 2016; Brown et al., 2017; Donoher et al., 2007).

\section{External Forces That Provide Opportunity}

External forces that provide opportunity to commit or facilitate wrongdoing consist of industry cultures and norms. Zahra et al. (2005) suggest that industry norms regarding payback periods and investment horizons set the tone for industry players and dictate CEO and, 
in turn, firm behavior. In more recent research, scholars have used industry norms around wrongdoing as independent variables to predict consequences claiming that differences in the perception of wrongdoing does, in fact, differ between industries (Zavyalova et al., 2012). Simple industry variables and complex industry concepts (e.g., social memory of industry wrongdoing) are also incorporated into recent studies to account for such external forces that may afford some firms a greater opportunity to engage in wrongdoing. Zahra et al. synthesize early fraud literature about the impact of other industry variables, such as concentration, on wrongdoing; however, this literature is limited and somewhat inconclusive. Since 2005, scholars have drawn new conclusions regarding the effect of firms' primary industry on the likelihood of wrongdoing. Ndofor et al. (2015) find that, similar to early reviews of the effect of firm-level complexity on information asymmetry and the likelihood of wrongdoing, industry-level complexities increase the likelihood of wrongdoing. These authors continue by studying the moderating effect of internal forces, such as CEO compensation and board monitoring. Simply, the opportunity that a complex industry provides CEOs is mitigated by aggressive board monitoring - the relationship between industry complexity and wrongdoing becomes more negative when board monitoring is aggressive. On the other hand, pressure applied via stock options strengthens the positive relationship between the opportunity a complex industry provides a CEO and wrongdoing.

Generally, scholars can also look beyond the boundary of the industry to the greater macroeconomy to understand firm action (Kluppel, Pierce, \& Snyder, 2017). In fact, evidence suggests that environmental factors outside of the industry influence misconduct. CEOs are more likely to engage in misconduct during prosperous economic times, and CEOs who began their careers in prosperous times are more likely to engage in such behavior later in their careers, according to Bianchi and Mohliver (2016). These authors suggest that this misbehavior is due to the accessibility of credit and capital. In sum, opportunity to engage in wrongdoing can be a reflection of a variety of environmental factors (i.e., industry and macroeconomic factors).

\section{Rationalization}

\section{The Inherent Nature of Rationalization}

The inherent nature of rationalization - a mental strategy - calls for a slightly different approach than previous sections of this review. Here, we lay the groundwork of rationalization by drawing from the microfoundations of CEO wrongdoing that include individual characteristics, personal ethics, and tendencies or interests. Individuals who engage in wrongdoing need a "suitable rationalization" in order to resolve the conflict between their action and societal ethics (Cressey, 1950; Trompeter et al., 2013). Sykes and Matza (1957) refer to this as "techniques of neutralization." In this review, as we look to internal and external forces that influence CEOs' misconduct, it is important to first understand which individuals are likely to rationalize before delving into forces that enable rationalization.

Many scholars have examined the relationship between CEO demographics and wrongdoing, as noted by previous reviews (e.g., Zahra et al., 2005) and extended by more recent scholars. However, here we are specifically interested in demographics that may contribute to rationalization. Recent scholarship suggests that younger CEOs are more likely to rationalize fraud, as are CEOs with less functional experience and without a business degree (Troy et al., 2011). These conclusions are somewhat contradictory to those described by Zahra et al. 
(2005). Previously reviewed, some studies find that business-related education may be related to fraudulent tendencies (e.g., Ferraro, Pfeffer, \& Sutton, 2005; Frank, Gilovich, \& Regan, 1993; Kelly, Ferrell, \& Skinner, 1990); however, Simpson and Koper (1997) found that CEOs with finance and administrative backgrounds were more likely to engage in antitrust violations than CEOs with other backgrounds. Multiple authors find gender influences on wrongdoing; specifically, male executives are more likely to engage in wrongdoing than female executives are, likely because of gender differences regarding temptation and self-control (Ramdani \& van Witteloostuijn, 2012; T. Tang \& Sutarso, 2013). Further, female CEOs are also more likely to be conservative in financial reporting and would find it harder to rationalize financial statement manipulation as a result (Ho, Li, Tam, \& Zhang, 2015).

While demographic variables in CEO research provide some insight, research in the past decade provides evidence of the effect of individual values and cognitions on the rationalization of wrongdoing. For instance, scholars have found that the CEO's personal ethics reduce the likelihood of fraud (T. Carpenter \& Reimers, 2005; Chen, 2010; Cohen, Ding, Lesage, \& Stolowy, 2012; Weber, 2010). They argue that stronger ethics or better moral reasoning reduces the ability to explain fraud to oneself as justified. Narcissism and tendency toward psychopathy increase the likelihood of fraud or unethical decision making (Rijsenbilt \& Commandeur, 2013; Stevens et al., 2012). A more optimistic and more realistic CEO is also more likely to be aggressive in financial reporting, which makes it easier to rationalize financial statement misreporting (Patelli \& Pedrini, 2015). Though limited in scope in comparison to research on pressures and opportunities, predicting fraud via understanding rationalization has begun to attract the attention of some accounting scholars. For instance, Davidson, Dey, and Smith (2015) found that CEOs with legal records are more likely to engage in wrongdoing, as are "unfrugal" CEOs. These findings reflect a perceived "loose" control environment. Generally, rationalization is different from the assessment of pressure and opportunity to engage in wrongdoing. However, in understanding who is more likely to rationalize, we can turn our attention to the internal and external forces that facilitate such rationalization.

\section{Internal Forces That Foster Rationalization}

Firm characteristics can enable CEO rationalization. Several scholars have explored the development and impact of deviant cultures (see Zahra et al., 2005, for a review); however, cultures characterized as "bad" or "deviant" are not the only kind that foster norms that facilitate wrongdoing. For instance, firms with higher-risk orientations foster the likelihood of corrupt behavior (Karmann, Mauer, Flatten, \& Brettel, 2016). Higher-risk-oriented firms engage in "bold moves" aimed at generating above-normal returns (Karmann et al., 2016: 227). Further, a focus on risk taking increases the scope of potential outcomes, which allows for more freedom with regard to means (including wrongful means) to accomplish these outcomes. On the other hand, innovativeness, another feature of entrepreneurial firms, is negatively related to wrongdoing (Karmann et al., 2016).

Although presumably well intentioned, firms with formal controls that fail to align the intention of those controls may be unintentionally focusing managers' attention on their own selfinterest. For instance, when controls are framed for coordinating purposes (e.g., budget reporting to provide important information to management regarding resource allocation) rather than for monitoring purposes (e.g., budgets as a control mechanism to evaluate spending 
behaviors), stronger controls result in more fraudulent reporting. In such firms, there is a greater likelihood of wrongdoing, underscoring the importance of consistent signals (Liu et al., 2015).

The structure of the relationship between firm owners and executives may also influence the ways in which CEOs make sense of wrongdoing. For instance, counter to traditional agency theory concepts, recent evidence provided by Connelly, Shi, and Zyung (2017) suggests concepts rooted in social exchange theory can explain why a CEO may not rationalize away wrongdoing but instead be motivated to do "the right thing." Specifically, these authors explain that CEOs are bound by principles of reciprocity; when shareholders formally give the CEO freedom, the CEO will, in turn, refrain from self-interested behavior (i.e., when the provisions that impose constraints on shareholder power increase, the likelihood of managerial misconduct decreases).

\section{External Forces That Foster Rationalization}

External forces may also foster bad behavior by nurturing rationalization. For instance, attorneys or accountants outside of the firm could promote or support misconduct, thus enabling a CEO to rationalize the act (Trompeter et al., 2013). CEOs of firms in industries with widespread wrongdoing already in progress could view wrongdoing as a necessary strategy. For example, options backdating was prominent between 1996 and 2005 (Heron \& Lie, 2006) and the practice spread via board interlocks (Bizjak, Lemmon, \& Whitby, 2009; Hogan, Rezaee, Riley, \& Velury, 2008). Banks and financial institutions picked up questionable mortgage and securitization practices that led to the financial crisis of 2007 to 2009 (Financial Crisis Inquiry Commission, 2011). After all, the ability to rationalize is easier if "everyone is doing it."

Globalization of business practices also forces CEOs into environments in which cultural norms and local corporate ethics may not align with Western concepts of ethics. Such misalignment could result in confusion over personal values and ethics and the ability to rationalize away certain behaviors (Statman, 2007).

\section{Assessment of the Current Literature}

To understand why CEO wrongdoing occurs, we need more than a laundry list of antecedents; rather, we must understand the pressure, opportunity, and rationalization of the CEO. Yet, much of our literature falls short of a comprehensive approach to these concepts. Here we reviewed literature primarily in the management discipline and published since 2005 by applying the Fraud Triangle conceptual model in a way that helps us to assess the current state of the literature. Albeit helpful in organizing empirical findings and providing a common language, this review has, more importantly, highlighted a dearth of study of interactions between the Fraud Triangle components as well as cross-level interactions. Figure 1 summarizes antecedents of CEO wrongdoing we review in this article.

\section{Future Research}

We begin our discussion of directions for future research by identifying gaps in the literature around each factor of the Fraud Triangle. On the basis of areas in which the current 
Figure 1

Antecedents of CEO Wrongdoing

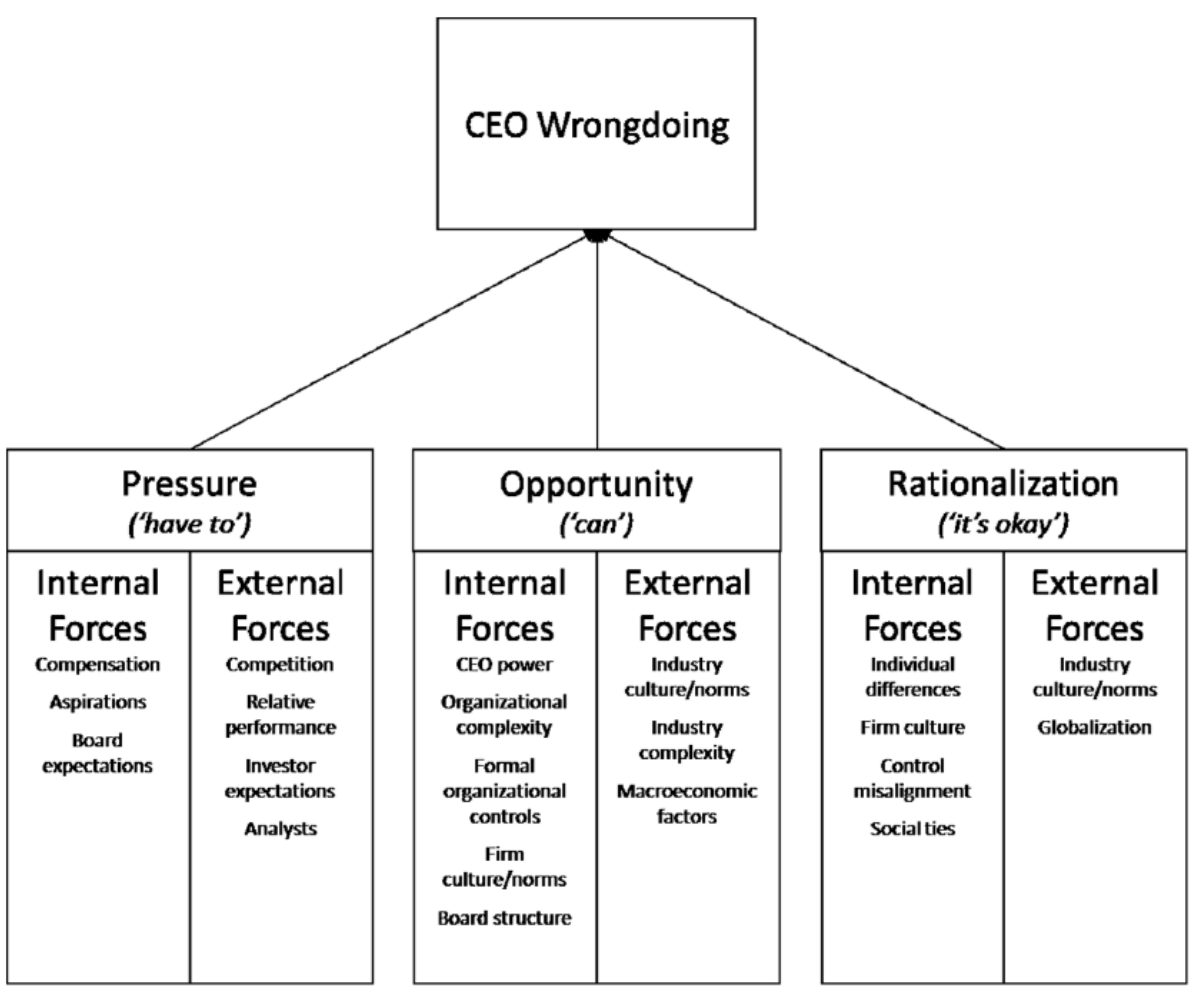

literature is incomplete and questions remain, we provide recommendations for future research, but we also make recommendations for other research outside of the scope of this review. Our recommendations include interactions and cross-level influences, wrongdoing and global nuances, recurrence of wrongdoing, and measurement and methodology.

\section{Future Research on Pressure}

In our review, scholars have primarily focused their efforts in uncovering individual-level pressures in the arena of compensation. However, there are still interesting and unaddressed questions about internal forces that impose pressure. For instance, according to our review, there has been little attention on pressure resulting from social evaluations of the CEO (e.g., high or low status or reputation). Similar to pressure resulting from aspirations associated with firm performance (Harris \& Bromiley, 2007; Mishina et al., 2010), is it possible that CEOs act in response to pressure associated with either enhancing or maintaining their personal status? Further, is this pressure even greater if the status of the organization or the board is greater than that of the CEO? 
The primary focus of research in the area of how firm characteristics increase pressure on the CEO has been on the effect of firm performance on the likelihood of wrongdoing. However, other kinds of pressure associated with the firm can include product-market competition. Are there aspects of competition that can lead to pressure within the firm to cut corners? Does a duopoly (one key rival) create more incentive or pressure to commit wrongdoing, or does perfect competition (many rivals)? If the firm is colocated with a rival, and is losing employees to the rival will that increase pressure to create, at least temporarily, a more positive work environment through misinformation?

Relative to other subsets of research regarding antecedents of wrongdoing, generally, and that associated with the board, specifically, there is very little research regarding the pressure facing the CEO generated by the board. Therefore, we suggest that scholars focus future research in this area. According to the research on the consequences of poor performance in the boardroom facing board members (Marcel \& Cowen, 2014; Naumovska, Wernickle, \& Zajac, 2017; Wurthmann, 2014), it is reasonable to suggest that board members and boards, as a collective, pressure the CEO to deliver, thus increasing the likelihood of wrongdoing. Recent research supports the effect of the board chair and who the board chair is on firm performance (Withers \& Fitza, 2017). Therefore, the board chair, specifically, may be in a position to exert pressure on the CEO. The board or its chair could exert pressure on the CEO if it is under pressure itself to meet announced earnings estimates or to keep improving performance. As the management literature increases its consideration of analysts in the strategy of the firm (e.g., Reid \& Toffel, 2009; Shi et al., 2017), critical questions by analysts and activist or institutional investors may reinforce pressure to misbehave on both the board and the CEO. Directors' compensation, especially their stocks and stock options, are a doubleedged sword. If directors hold only a few stocks and stock options, the incentive to monitor the CEO may be low, thereby increasing his or her opportunity for corporate wrongdoing. In the case of large amounts of stocks and stock options, there may be additional pressure on the board to increase performance, thereby amplifying the pressure on the CEO and indirectly contributing to organizational wrongdoing (e.g., Berenson, 2003). Other stakeholders, such as the media, which have grown in popularity as a concept in the wrongdoing literature, could also apply pressure to engage in wrongdoing, as we know that such stakeholders' negative evaluations (e.g., media attacks) influence the way in which CEOs behave (Durand \& Vergne, 2015).

\section{Future Research on Opportunity}

Opportunity opens the way for wrongdoing. Without opportunity, the CEO may not be able to misbehave regardless of the pressure to do so or his or her ability to rationalize. Yet, the most underexplored component of the Fraud Triangle, as it reflects the CEO, is in the area of opportunity. While some scholars have identified CEO power (structural, ownership, and informational) as an important indicator of opportunity to engage in wrongdoing, there is relatively little empirical evidence of the nuances of this power and its true effect on organizational wrongdoing. Recent scholarship focused on the power dynamics between the CEO and board and the appointment of a lead independent director (Krause, Withers, \& Semadeni, 2017) implies the dynamic nature of CEO power. Taken together, several questions surface. Are there moderators that can shape the influence of that power on the CEO's opportunity? For example, if the board is very knowledgeable about the firm and the industry, does that 
weaken the influence of informational power? Does a director with high status weaken the effect of structural power?

Further, what, besides power, provides the CEO with the opportunity to misbehave? Is it possible that tenure relative to other organizational members may afford the CEO the opportunity to engage in wrongdoing? Longer service than other organizational members (be it the top management team or the board) might influence the CEO's ability to commit wrongdoing because rookies may not have the credibility to whistle-blow and, therefore, be more likely to turn a "blind eye." Recent scholarship that takes a more nuanced approach to understanding the relationship between the board, its chair, and the CEO (Krause, 2017; Oliver, Krause, Busenbark, \& Kalm, 2018) provides fruitful insights that could inform the opportunities that CEOs have to misbehave. For instance, while a separation of chair and CEO roles has historically indicated a greater control over CEO behavior, new scholarship supports that some chairs demonstrate a collaborative versus control orientation. How might chair orientation change the opportunity afforded to CEOs to engage in wrongdoing? Further, evidence suggests that there may be benevolent sexism in the boardroom such that board chairs are more likely to collaborate with female CEOs than with male CEOs (Oliver et al., 2018). Combined, it could be beneficial to explore individual differences between board chairs and between CEOs to explain why some CEOs have more opportunity to misbehave than others and if they take that opportunity. The amount of distraction that a CEO can create (e.g., corporate social responsibility [CSR] initiatives, social entrepreneurship, or celebrity) could also result in opportunity to commit wrongdoing "under the radar." Similarly, scholars can draw from conclusions regarding goodwill and insurance-like effects of CSR (Godfrey, Merrill, \& Hansen, 2009) as opportunities to engage in misconduct. Does this form of insurance even reduce the likelihood of being caught?

Firm characteristics that can allow the CEO greater opportunities to misbehave include internal controls and firm culture. Much has been done in this area. However, marrying literatures, we recommend exploration of entrepreneurial concepts and wrongdoing. For instance, perhaps drawing from the aspirational literature or that of organizational decline (Chng, Rodgers, Shih, \& Song, 2015; McKinley, Latham, \& Braun, 2014; Trahms, Ndofor, \& Sirmon, 2013), how might entrepreneurial failures enhance the likelihood of wrongdoing? Further, piggybacking on previous literature on the effects of slack on CEO behavioral tendencies (Martin, Wiseman, \& Gomez-Mejia, 2016; Sonenshein, 2014), is it possible that greater slack and higher discretionary accruals can also amplify the opportunity for the CEO to commit wrongdoing? Finally, scholars suggest that complexity facilitates wrongdoing. Different ways firms can be complex include high levels of $R \& D$, fast cycle times, or diversification while remaining highly integrated. Thus, how might R\&D with uncertain time horizons and probabilities of success provide opportunity to commit wrongdoing?

Opportunities to commit wrongdoing may reflect the level of activity of the board (e.g., active board vs. passive board) or the misalignment of the board, which can lead to underutilization of important board functions (Garg \& Eisenhardt, 2017). Further, CEOs can avoid engaging in behaviors that would result in a better use of board resources (e.g., expertise and advice), such as fostering dyadic interactions and strategic brainstorming with the board (Garg \& Eisenhardt, 2017), and instead use an arm's-length approach in his or her relationship with the board. In such a case, the CEO could reasonably construct his or her own environment of opportunity. The board can also enhance the opportunity for wrongdoing, for 
instance, through a low vigilance or ability to monitor the CEO. Scholars may find it fruitful to explore the effects of busy directors, pluralistic ignorance, and socialization to a low monitoring standard (increasing the tendency to "just go along" and not speak up in meetings) on wrongdoing. The most prevalent board issues from our review are those regarding monitoring behaviors. However, we did not find answers to other questions such as how "bad boards"-boards that include compromised or unethical board members or "bad board chairs"-might influence CEOs to commit wrongdoing. It is also possible that such "bad boards" could facilitate the transfer of fraudulent knowledge and skills, underscoring a dark side of organizational learning. Some work has been done in the area of "spillover," the effect of ties to wrongdoers, but such conclusions have been drawn from unique samples (e.g., sports) and have not been validated at the board level (Palmer \& Yenkey, 2013). Recent research on emotions (e.g., guilt, shame, embarrassment, and pride) and their influence on the spread of corruption provide yet another foundation on which to build future research (Smith-Crowe \& Warren, 2014). Further, some research has begun to explore the influence of observation of peers' punishment following wrongdoing on the focal firm's likelihood to misbehave (Yiu, Xu, \& Wan, 2014). These efforts integrate concepts from multiple disciplines and offer a jump start on future research regarding the opportunity to misbehave.

\section{Future Research on Rationalization}

Scholars have also conducted noteworthy research regarding which CEOs are likely to rationalize their wrongdoing; this research is primarily interested in CEO personality (e.g., narcissism) or demographics (e.g., gender). However, future research may gain additional insight by exploring behaviors that may increase the CEO's ability to rationalize misbehavior. For instance, how does participation in socially responsible activities influence the CEO's ability to justify misconduct (e.g., "it doesn't matter how we generated the revenue if it is improving the well-being of others")? We recommend continuing to explore the microfoundations of CEO wrongdoing by integrating personality literature. Further, scholars could uncover answers to questions about risky decision making and unethical decisions by delving deeper into psychology literatures.

The vast gap in the literature regarding firm characteristics that can allow the CEO to rationalize his or her wrongdoing welcomes the most future research. Beyond firm characteristics that inadvertently highlight self-interested behavior (e.g., inconsistent signals; Liu et al., 2015), which firm characteristics allow the CEO to rationalize wrongdoing? Linking the literature on organizational decline and turnaround (Carmeli \& Schaunbroeck, 2006; Mone, McKinley, \& Barker, 1998; Whetten, 1980) to the literature on wrongdoing, does being a CEO of a firm in decline make it easier to rationalize wrongdoing? When firms' focus turns to survival, can CEOs rationalize "whatever it takes?"

There is abundant space for exploration of how CEOs might rationalize wrongdoing as a reflection of their board. We encourage scholars to explore not only how boards provide opportunity to commit wrongdoing but also how they may allow the CEO to rationalize it. For instance, CEOs could rationalize wrongdoing if "rookie boards" or specific board chairs failed to catch or unintentionally encouraged bad behavior. This may also be a result of boards' lack of skills (e.g., the board made an error or did not catch an error) or voice (i.e., directors failed to voice concern over strategy). Concepts of pluralistic ignorance may help 


\section{Table 2}

\section{Directions for Future Research}

\begin{tabular}{|c|c|c|}
\hline Antecedent & Internal Forces & External Forces \\
\hline Pressure & $\begin{array}{l}\text { What is the effect of CEO status on } \\
\text { wrongdoing? } \\
\text { Does product-market competition create } \\
\text { pressure for wrongdoing? }\end{array}$ & $\begin{array}{l}\text { Other than media and investors, what other } \\
\text { external stakeholders apply pressure to } \\
\text { commit wrongdoing? } \\
\text { What kind of media pressures influence the } \\
\text { likelihood of CEO wrongdoing? }\end{array}$ \\
\hline Opportunity & $\begin{array}{l}\text { What kinds of "distractions" can a CEO } \\
\text { create that allow the opportunity to } \\
\text { misbehave without detection? } \\
\text { How are slack and executive discretion } \\
\text { related to CEO wrongdoing? } \\
\text { What are the effects of R\&D uncertainties on } \\
\text { wrongdoing? }\end{array}$ & $\begin{array}{l}\text { How do other 'bad" firms' behaviors or } \\
\text { consequences influence the focal CEO's } \\
\text { behavior? } \\
\text { Do external stakeholders' lack of attention } \\
\text { provide opportunity for CEO wrongdoing? } \\
\text { Do external stakeholders' idealized portrayal } \\
\text { of firms/CEOs provide opportunity for CEO } \\
\text { wrongdoing? }\end{array}$ \\
\hline Rationalization & $\begin{array}{l}\text { What are the microfoundations of CEO } \\
\text { wrongdoing? } \\
\text { What is the relationship between uncertainty } \\
\text { associated with organizational events, such } \\
\text { as mergers and acquisitions, and CEO } \\
\text { wrongdoing? } \\
\text { What are the effects of "rookie directors" with } \\
\text { lack of skill on CEO wrongdoing? }\end{array}$ & $\begin{array}{l}\text { How do changes in rules or regulations effect } \\
\text { CEO wrongdoing? } \\
\text { How does the political environment influence } \\
\text { CEO wrongdoing? }\end{array}$ \\
\hline
\end{tabular}

explain the board's role in the CEO's wrongdoing much as it relates to strategic change (Westphal \& Bednar, 2005). A director's fear of looking uninformed inhibits questions. These boards are very likely, then, to make it easier for the CEO to rationalize wrongdoing because from the CEO's perspective, the board never opposed the CEO.

The external environment, even beyond the industry level, as supported by the work of Bianchi and Mohliver (2016), influences the likelihood of wrongdoing; for example, CEOs are more likely to backdate in prosperous times. Other environmental factors that could influence the CEO's wrongdoing include changing rules and regulations and even political shifts. A high potential direction for future research, though not without challenge, includes an examination of environmental factors on CEO rationalization. Table 2 provides a sample of research questions that could contribute to a more complete understanding of CEO wrongdoing within the Fraud Triangle framework. While these questions are likely to contribute to the literature in meaningful ways, we introduce additional concepts that may prove productive in addressing the complexities associated with wrongdoing.

\section{Interactions and Cross-Level Influences}

More often than not, literature on CEO wrongdoing focuses on the direct effects the components of the Fraud Triangle have on the likelihood of such behavior. However, drawing from our review of the literature and its conclusions, research that will extend our understanding of the relationships and interactions between the Fraud Triangle components will be important to the evolution of wrongdoing research. We encourage exploration of questions 
that our framework highlights, such as the following: Are variables that measure one dimension of the Fraud Triangle substitutes or complements? For example, do options and reputational pressure exert the same effect on a CEO's tendency to commit wrongdoing? Or when they are both present, do they exert additive or even multiplicative pressure? Or, with respect to opportunity, how do outside constituents' evaluations exacerbate internal opportunities to commit wrongdoing?

Perhaps the most important question as a result of this review revolves around the idea of the interaction between the factors of the Fraud Triangle: Are all three Fraud Triangle dimensions (pressure, opportunity, and rationalization) equally important? Are some of them more important under different circumstances - for example, at different stages of the firm's life cycle or when the firm is undertaking a large strategic move, such as a merger or acquisition? If so, how do the factors interrelate with each other? Are the factors additive or multiplicative? If one of the Fraud Triangle dimensions is not present at all, will wrongdoing still occur?

\section{Wrongdoing and Global Nuances}

We restricted our review to the United States, as the formal and informal institutions that are associated with wrongdoing vary by country. However, there is a considerable amount of wrongdoing research utilizing samples or concepts unique to countries other than the United States. For instance, several authors have explored internal and external forces in an effort to understand the occurrence of fraud within other countries (e.g., Cumming, Leung, \& Rui, 2015; Jeong \& Weiner, 2012; Jing \& Graham, 2008; Lisic, Silveri, Song, \& Wang, 2015). But samples drawn from outside of the United States face different formal and informal institutions that can influence how the CEO feels pressure, creates or is provided opportunity, and rationalizes wrongdoing. Other countries' institutions also influence the firm's role and the board's ability to interact with the CEO and his or her propensity to commit wrongdoing. State ownership influences monitors' ability to effectively reduce the occurrence of fraud. For instance, Spencer and Gomez (2011) examine the corrupt nature of both the host and home country environments as pressure on multinational enterprise subsidiaries to engage in wrongdoing. Generally, it is apparent that foreign samples uncover nuances that reflect specific types of wrongdoing and unique circumstances in which wrongdoing can occur, but do these influences occur in domestic samples, too?

Comparative studies provide opportunity and can bring greater understanding to how important or influential individual countries' institutions are. Multistudy (e.g., replication and comparison across samples) research will provide insight regarding similarities and differences between samples and offer the chance to draw conclusions about global deterrents to engage in wrongdoing. Further, examining the propensity and antecedents of firms in the United States to engage in wrongdoing in host countries would be a way to further extend the antecedents of wrongdoing literature.

\section{Recurrence of Wrongdoing and Other Firm Disruptions}

Wrongdoing can reoccur (Pinto et al., 2008). Some studies have tried to bolster our understanding of which firms and firm leaders continue to misbehave (i.e., never stop) or which firms and leaders have a recurrence (i.e., stop but start again). As our review highlights, CEO, firm, and board characteristics that are antecedents to wrongdoing are hard to change, as are 
characteristics of the industry and macroeconomy that are completely out of the control of the firm and its leaders. Whereas a board can fire a CEO for committing wrongdoing, it is much harder to change the firm's policies and procedures, let alone its culture. Relatedly, in theory, a board can be completely refreshed following wrongdoing (i.e., turnover), but it is unlikely. Several board members may depart (Arthaud-Day, Certo, Dalton, \& Dalton, 2006), but the culture of the board, its tendency to not question the CEO, for example, will be the board culture that socializes new directors (Westphal \& Zajac, 2013). For these reasons, we strongly encourage research in the persistence of wrongdoing.

Scholars could investigate other major events in the life of the firm (e.g., mergers and acquisitions, restructuring, etc.) to explore the role that disruption throughout the firm plays on the occurrence of wrongdoing. These events likely involve all three components of the Fraud Triangle. Several studies have explored restructuring (e.g., succession events) following wrongdoing (Connelly, Ketchen, Gangloff, \& Shook, 2016; Gangloff, Connelly, \& Shook, 2016; Gomulya \& Boeker, 2016; Marcel \& Cowen, 2014); none, according to our review, focus on the effect of restructuring on the likelihood, type, or severity of future wrongdoing. Is there something about a post-restructuring context that makes wrongdoing more likely?

\section{Measurement and Methodology}

In our review of the literature, we discovered that scholars use many different measures for very similar constructs (i.e., wrongdoing), yet we know that small differences in the way a measure is identified and calculated can dramatically change results. We recommend that future research uses multiple measures (e.g., acts of wrongdoing, earnings restatements, Foreign Corrupt Practices Act violations, etc.) or multiple studies to better capture and triangulate the phenomenon of wrongdoing. To the extent that more than one database carries the same incident, versus only one database, this might lead to interesting comparisons and tests. Each database measures a different type of detection; several databases integrated into one can tell a more complete story of wrongdoing. We also recommend further examination of the ways in which mistakes, that is, accidental wrongdoing, can or should be integrated into the literature of wrongdoing. While the intentionality is different, are other components of the wrongdoing the same? Does an accident lead to wrongdoing? In future research that measures wrongdoing, because most measures rely on discovery of wrongdoing, we encourage scholars in this area to be very clear concerning when the wrongdoing is occurring versus when it is discovered. There may be lags in time and issues with the accuracy of the type or severity of wrongdoing when we rely on the announcement of wrongdoing. These deficiencies provide opportunity for contribution to the literature.

\section{Conclusion}

We extend earlier reviews by updating general conclusions about CEO wrongdoing based on recent research but, more importantly, by adapting an explanatory conceptual model of wrongdoing originally utilized in accounting literature. The Fraud Triangle provides a common framework within which we can understand the current body of literature on the antecedents of CEO wrongdoing. Furthermore, using this conceptual lens, we offer a useful agenda for future research that will bring us closer to explaining why CEOs misbehave. 


\section{Notes}

1. The romanticization of leadership also suggests an attribution of organizational events and occurrences to the CEO; as explained by Meindl, Ehrlich, and Dukerich (1985), leadership is perhaps best construed as an explanatory category that can be used to explain and account for organizational activities and outcomes. Further, highlighted in the scapegoating literature (Gamson \& Scotch, 1964; Gangloff, Connelly, \& Shook, 2016; Rowe, Cannella, Rankin, \& Gorman, 2005), even if the CEO is not directly responsible for the firm's wrongdoing, he or she is often blamed. These theories do not, necessarily, compete with that of upper echelons but, instead, explain a post hoc cognitive process or strategy to influence stakeholder sensemaking.

2. Greve, Palmer, and Pozner (2010) published a broad, theoretical form of review that is largely focused on their body of work. Here we focus more deeply and exclusively on the antecedents of wrongdoing as well as the current state of empirical research.

3. Note that in these definitions and examples, accounting misstatements or financial misstatements are a subset of fraud, which is a subset of wrongdoing.

\section{References}

References marked with an asterisk indicate studies on CEO wrongdoing in the United States and are reviewed in this paper.

*Agrawal, A., \& Chadha, S. 2005. Corporate governance and accounting scandals. Journal of Law and Economics, 48: 371-406.

Aguilera, R. V., \& Vadera, A. K. 2008. The dark side of authority: Antecedents, mechanisms, and outcomes of organizational corruption. Journal of Business Ethics, 77: 431-449.

Akkah, I. P. 1996. The influence of organizational rank and role on marketing professionals' ethical judgments. Journal of Business Ethics, 15: 605-614.

Albrecht, W. S., Howe, K. R., \& Romney, M. B. 1984. Deterring fraud: The internal auditor's perspective. Lake Mary, FL: Institute of Internal Auditors.

*Amiram, D., Bozanic, Z., Cox, J. D., Dupont, J. M., Karpoff, J. M., \& Sloan, R. G. in press. Financial reporting fraud and other forms of misconduct: A multidisciplinary review of the literature. Review of Accounting Studies.

Anand, V., Ashforth, B. E., \& Joshi, M. 2004. Business as usual: The acceptance and perpetuation of corruption in organizations. Academy of Management Executive, 18: 39-53.

Arthaud-Day, M. L., Certo, S. T., Dalton, C. M., \& Dalton, D. R. 2006. A changing of the guard: Executive and director turnover following corporate financial restatements. Academy of Management Journal, 49: 1119-1136.

*Ashforth, B. E., Gioia, D. A., Robinson, S. L., \& Trevino, L. K. 2008. Re-viewing organizational corruption. Academy of Management Review, 33: 670-684.

Association of Certified Fraud Examiners. 2014. Report to the nations on occupational fraud and abuse: 2014 global fraud study. Austin, TX: Author. Retrieved from https://www.acfe.com/rttn/docs/2014-report-to-nations.pdf

*Ayers, S., \& Kaplan, S. E. 2005. Wrongdoing by consultants: An examination of employees' reporting intentions. Journal of Business Ethics, 57: 121-137.

*Bennett, V. M., Pierce, L., Snyder, J. A., \& Toffel, M. W. 2013. Customer-driven misconduct: How competition corrupts business practices. Management Science, 59: 1725-1742.

Berenson, A. 2003. The number: How the drive for quarterly earnings corrupted Wall Street and corporate America. New York: Random House.

Bianchi, E. C., \& Mohliver, A. 2016. Do good times breed cheats? Prosperous times have immediate and lasting implications for CEO misconduct. Organization Science, 27: 1488-1503.

Bizjak, J., Lemmon, M., \& Whitby, R. 2009. Option backdating and board interlocks. Review of Financial Studies, 22: 4821-4847.

Boivie, S., Bednar, M. K., Aguilera, R. V., \& Andrus, J. L. 2016. Are boards designed to fail? The implausibility of effective board monitoring. Academy of Management Annals, 10: 319-407.

Brown, J. A., Anderson, A., Salas, J. M., \& Ward, A. J. 2017. Do investors care about director tenure? Insights from executive cognition and social capital theories. Organization Science, 28: 471-494.

Burns, N., \& Kedia, S. 2006. The impact of performance-based compensation on misreporting. Journal of Financial Economics, 79: 35-67. 
Burns, N., \& Kedia, S. 2008. Executive option exercises and financial misreporting. Journal of Banking \& Finance, 32: $845-857$.

Carberry, E. J., \& King, B. G. 2012. Defensive practice adoption in the face of organizational stigma: Impression management and the diffusion of stock option expensing. Journal of Management Studies, 49: 1137-1167.

Carmeli, A., \& Schaubroeck, J. 2006. Top management team behavioral integration, decision quality, and organizational decline. Leadership Quarterly, 17: 441-453.

Carpenter, M. A., Geletkanycz, M. A., \& Sanders, W. G. 2004. Upper echelons research revisited: Antecedents, elements, and consequences of top management team composition. Journal of Management, 30: 749-778.

*Carpenter, T. D., \& Reimers, J. L. 2005. Unethical and fraudulent financial reporting: Applying the theory of planned behavior. Journal of Business Ethics, 60: 115-129.

Cecchini, M., Aytug, H., Koehler, G. J., \& Pathak, P. 2010. Detecting management fraud in public companies. Management Science, 56: 1146-1160.

*Chakrabarty, S. 2015. The influence of unrelated and related diversification on fraudulent reporting. Journal of Business Ethics, 131: 815-832.

*Chen, S. 2010. The role of ethical leadership versus institutional constraints: A simulation study of financial misreporting by CEOs. Journal of Business Ethics, 93: 33-52.

Chng, D. H. M., Rodgers, M. S., Shih, E., \& Song, X. B. 2015. Leaders' impression management during organizational decline: The roles of publicity, image concerns, and incentive compensation. Leadership Quarterly, 26: $270-285$

Cline, B. N., Walking, R. A., \& Yore, A. S. 2017. The consequences of managerial indiscretions: Sex, lies, and firm value. Journal of Financial Economics, 127: 389-415.

*Cohen, J., Ding, Y., Lesage, C., \& Stolowy, H. 2012. Corporate fraud and managers' behavior: Evidence from the press. In R. Cressy, D. Cumming, \& C. Mallin (Eds.), Entrepreneurship, governance and ethics: 271-315. Dordrecht, Netherlands: Springer.

Coleman. 1985. The criminal elite: The sociology of white-collar crime. Englewood Cliffs, NJ: Prentice Hall.

*Combs, J. G., Ketchen, D. J., Perryman, A. A., \& Donahue, M. S. 2007. The moderating effect of CEO power on the board composition-firm performance relationship. Journal of Management Studies, 44: 1299-1323.

Connelly, B. L., Ketchen, D. J., Gangloff, K. A., \& Shook, C. L. 2016. Investor perceptions of CEO successor selection in the wake of integrity and competence failures: A policy capturing study. Strategic Management Journal, 37: 2135-2151.

*Connelly, B. L., Shi, W., \& Zyung, J. 2017. Managerial response to constitutional constraints on shareholder power. Strategic Management Journal, 38: 1499-1517.

*Cowen, A. P., \& Marcel, J. J. 2011. Damaged goods: Board decisions to dismiss reputationally compromised directors. Academy of Management Journal, 54: 509-527.

Cressey, D. R. 1950. The criminal violation of financial trust. American Sociological Review, 15: 738-743.

Cressey, D. R. 1953. Other people's money: A study of the social psychology of embezzlement. New York: Free Press.

*Cumming, D., Leung, T. Y., \& Rui, O. 2015. Gender diversity and securities fraud. Academy of Management Journal, 58: 1572-1593.

Daily, C. M., Dalton, D. R., \& Cannella, A. A. 2003. Corporate governance: Decades of dialogue and data. Academy of Management Review, 28: 371-382.

*Dalton, D., \& Radtke, R. R. 2013. The joint effects of Machiavellianism and ethical environment on whistleblowing. Journal of Business Ethics, 117: 153-172.

Davidson, R. H., Dey, A., \& Smith, A. J. 2015. Executives' “off-the-job” behavior, corporate culture, and financial reporting risk. Journal of Financial Economics, 117: 5-28.

*Davis, J. L., Payne, G. T., \& McMahan, G. C. 2007. A few bad apples? Scandalous behavior of mutual fund managers. Journal of Business Ethics, 76: 319-334.

Denis, D. J., Hanouna, P., \& Sarin, A. 2006. Is there a dark side to incentive compensation? Journal of Corporate Finance, 12: 467-488.

Desai, H., Hogan, C. E., \& Wilkins, M. S. 2006. The reputational penalty for aggressive accounting: Earnings restatements and management turnover. Accounting Review, 81: 83-112.

Deutsch, Y., Keil, T., \& Laamanen, T. 2011. A dual agency view of board compensation: The joint effects of outside director and CEO stock options on firm risk. Strategic Management Journal, 32: 212-227.

*Dionne, G., Giuliano, F., \& Picard, P. 2009. Optimal auditing with scoring: Theory and application to insurance fraud. Management Science, 55: 58-70. 
*Donoher, W. J., Reed, R., \& Storrud-Barnes, S. F. 2007. Incentive alignment, control, and the issue of misleading financial disclosures. Journal of Management, 33: 547-569.

Dorminey, J., Fleming, A. S., Kranacher, M. J., \& Riley, R. A., Jr. 2012. The evolution of fraud theory. Issues in Accounting Education, 27: 555-579.

Dowell, G. W., Shackell, M. B., \& Stuart, N. V. 2011. Boards, CEOs, and surviving a financial crisis: Evidence from the Internet shakeout. Strategic Management Journal, 32: 1025-1045.

Durand, R., \& Vergne, J. P. 2015. Asset divestment as a response to media attacks in stigmatized industries. Strategic Management Journal, 36: 1205-1223.

Earle, J. S., Spicer, A., \& Peter, K. S. 2010. The normalization of deviant organizational practices: Wage arrears in Russia, 1991-98. Academy of Management Journal, 53: 218-237.

Erickson, M., Hanlon, M., \& Maydew, E. L. 2006. Is there a link between executive equity incentives and accounting fraud? Journal of Accounting Research, 44: 113-143.

Fama, E. F. 1980. Agency problems and the theory of the firm. Journal of Political Economy, 88: 288-307.

Ferraro, F., Pfeffer, J., \& Sutton, R. I. 2005. Economics language and assumptions: How theories can become selffulfilling. Academy of Management Review, 30: 8-24.

Financial Crisis Inquiry Commission. 2011. The financial crisis inquiry report, authorized edition: Final report of the National Commission on the Causes of the Financial and Economic Crisis in the United States. New York: Public Affairs.

Finkelstein, S., \& Hambrick, D. C. 1996. Strategic leadership: Top executives and their effects on organizations. Minneapolis/St. Paul, MN: West Publishing.

Frank, R. H., Gilovich, T., \& Regan, D. T. 1993. Does studying economics inhibit cooperation? Journal of Economic Perspectives, 7: 159-171.

Gamson, W. A., \& Scotch, N. A. 1964. Scapegoating in baseball. American Journal of Sociology, 70: 69-72.

*Gangloff, K. A., Connelly, B. L., \& Shook, C. L. 2016. Of scapegoats and signals: Investor reactions to CEO succession in the aftermath of wrongdoing. Journal of Management, 42: 1614-1634.

Garg, S., \& Eisenhardt, K. M. 2017. Unpacking the CEO-board relationship: How strategy making happens in entrepreneurial firms. Academy of Management Journal, 60: 1828-1858.

Gino, F., \& Pierce, L. 2010. Robin Hood under the hood: Wealth-based discrimination in illicit customer help. Organization Science, 21: 1176-1194.

Godfrey, P. C., Merrill, C. B., \& Hansen, J. M. 2009. The relationship between corporate social responsibility and shareholder value: An empirical test of the risk management hypothesis. Strategic Management Journal, 30: 425-445.

Gomulya, D., \& Boeker, W. 2016. Reassessing board member allegiance: CEO replacement following financial misconduct. Strategic Management Journal, 37: 1898-1918.

Greve, H. R., Palmer, D., \& Pozner, J. E. 2010. Organizations gone wild: The causes, processes, and consequences of organizational misconduct. Academy of Management Annals, 4: 53-107.

Gupta, A., Briscoe, F., \& Hambrick, D. 2017. Evenhandedness in resources allocation: Its relationship with CEO ideology, organizational discretion, and firm performance. Academy of Management Journal. Advance online publication.

Hadani, M., Goranova, M., \& Khan, R. 2011. Institutional investors, shareholder activism, and earnings management. Journal of Business Research, 64: 1352-1360.

Hambrick, D. C. 2007. Upper echelons theory: An update. Academy of Management Review, 32: 334-343.

Hambrick, D. C., \& Mason, P. A. 1984. Upper echelons: The organization as a reflection of its top managers. Academy of Management Review, 9: 193-206.

Hannah, D. R. 2005. Should I keep a secret? The effects of trade secret protection procedures on employees' obligations to protect trade secrets. Organization Science, 16: 71-84.

Harris, J., \& Bromiley, P. 2007. Incentives to cheat: The influence of executive compensation and firm performance on financial misrepresentation. Organization Science, 18: 350-367.

Heron, R. A., \& Lie, E. 2006. On the use of poison pills and defensive payouts by takeover targets. Journal of Business, 79: 1783-1807.

*Ho, S. S., Li, A. Y., Tam, K., \& Zhang, F. 2015. CEO gender, ethical leadership, and accounting conservatism. Journal of Business Ethics, 127: 351-370.

Hogan, C. E., Rezaee, Z., Riley, R. A., \& Velury, U. K. 2008. Financial statement fraud: Insights from the academic literature. Auditing: A Journal of Practice \& Theory, 27: 231-252. 
Hopkins, J. J., Maydew, E. L., \& Venkatachalam, M. 2014. Corporate general counsel and financial reporting quality. Management Science, 61: 129-145.

Hutton, I., Jiang, D., \& Kumar, A. 2015. Political values, culture, and corporate litigation. Management Science, 61: 2905-2925.

Jap, S., Robertson, D. C., \& Hamilton, R. 2011. The dark side of rapport: Agent misbehavior face-to-face and online. Management Science, 57: 1610-1622.

Jeong, Y., \& Weiner, R. J. 2012. Who bribes? Evidence from the United Nations' oil-for-food program. Strategic Management Journal, 33: 1363-1383.

Jing, R., \& Graham, J. L. 2008. Values versus regulations: How culture plays its role. Journal of Business Ethics, 80: 791-806.

*Johnson, S. A., Ryan, H. E., \& Tian, Y. S. 2009. Managerial incentives and corporate fraud: The sources of incentives matter. Review of Finance, 13: 115-145.

Johnson, S. G., Schnatterly, K., \& Hill, A. D. 2013. Board composition beyond independence: Social capital, human capital, and demographics. Journal of Management, 39: 232-262.

*Kang, E. 2008. Director interlocks and spillover effects of reputational penalties from financial reporting fraud. Academy of Management Journal, 51: 537-555.

Kaptein, M. 2008. Developing a measure of unethical behavior in the workplace: A stakeholder perspective. Journal of Management, 34: 978-1008.

*Karmann, T., Mauer, R., Flatten, T. C., \& Brettel, M. 2016. Entrepreneurial orientation and corruption. Journal of Business Ethics, 133: 223-234.

Karpoff, J. M., Koester, A., Lee, D. S., \& Martin, G. S. 2017. Proxies and databases in financial misconduct research. Accounting Review, 92: 129-163.

Kelly, S. W., Ferrell, O. C., \& Skinner, S. M. 1990. Ethical behavior among marketing researchers: An assessment of selected demographic characteristics. Journal of Business Ethics, 9: 681-688.

Kluppel, L. M., Pierce, L., \& Snyder, J. A. 2017. The deep historical roots of organization and strategy: Traumatic shocks, culture, and institutions. Organizational Science. Advance online publication.

Krause, R. 2017. Being the CEO's boss: An examination of board chair orientations. Strategic Management Journal, 38: 697-713.

Krause, R., Withers, M. C., \& Semadeni, M. 2017. Compromise on the board: Investigating the antecedents and consequences of lead independent director appointment. Academy of Management Journal, 60: 2239-2265.

Krishnan, R., \& Kozhikode, R. K. 2015. Status and corporate illegality: Illegal loan recovery practices of commercial banks in India. Academy of Management Journal, 58: 1287-1312.

Langton, L., \& Piquero, N. L. 2007. Can general strain theory explain white-collar crime? A preliminary investigation of the relationship between strain and select white-collar offenses. Journal of Criminal Justice, 35: 1-15.

*Lie, E. 2005. On the timing of CEO stock option awards. Management Science, 51: 802-812.

Lim, E. N., \& McCann, B. T. 2013. The influence of relative values of outside director stock options on firm strategic risk from a multiagent perspective. Strategic Management Journal, 34: 1568-1590.

Lisic, L. L., Silveri, S. D., Song, Y., \& Wang, K. 2015. Accounting fraud, auditing, and the role of government sanctions in China. Journal of Business Research, 68: 1186-1195.

*Liu, X. K., Wright, A. M., \& Wu, Y. J. 2015. Managers' unethical fraudulent financial reporting: The effect of control strength and control framing. Journal of Business Ethics, 129: 295-310.

*MacLean, T. L., \& Behnam, M. 2010. The dangers of decoupling: The relationship between compliance programs, legitimacy perceptions, and institutionalized misconduct. Academy of Management Journal, 53: 1499-1520.

*Malhotra, D., \& Gino, F. 2011. The pursuit of power corrupts: How investing in outside options motivates opportunism in relationships. Administrative Science Quarterly, 56: 559-592.

*Marcel, J. J., \& Cowen, A. P. 2014. Cleaning house or jumping ship? Understanding board upheaval following financial fraud. Strategic Management Journal, 35: 926-937.

Martin, G. P., Wiseman, R. M., \& Gomez-Mejia, L. R. 2016. Going short-term or long-term? CEO stock options and temporal orientation in the presence of slack. Strategic Management Journal, 37: 2463-2480.

Mayer, D. M., Aquino, K., Greenbaum, R. L., \& Kuenzi, M. 2012. Who displays ethical leadership, and why does it matter? An examination of antecedents and consequences of ethical leadership. Academy of Management Journal, 55: 151-171.

McGrath, M. 2016. How the Wells Fargo phony account scandal sunk John Stumpf. Forbes. Retrieved from https:// www.forbes.com/sites/maggiemcgrath/2016/09/23/the-9-most-important-things-you-need-to-know-aboutthe-well-fargo-fiasco/\#1c92734e3bdc 
McKinley, W., Latham, S., \& Braun, M. 2014. Organizational decline and innovation: Turnarounds and downward spirals. Academy of Management Review, 39: 88-110.

Meindl, J. R., Ehrlich, S. B., \& Dukerich, J. M. 1985. The romance of leadership. Administrative Science Quarterly, 30: 78-102.

Merton, R. K. 1938. Social structure and anomie. American Sociological Review, 3: 672-682.

*Mishina, Y., Dykes, B. J., Block, E. S., \& Pollock, T. G. 2010. Why "good" firms do bad things: The effects of high aspirations, high expectations, and prominence on the incidence of corporate illegality. Academy of Management Journal, 53: 701-722.

Mone, M. A., McKinley, W., \& Barker, V. L. 1998. Organizational decline and innovation: A contingency framework. Academy of Management Review, 23: 115-132.

Morales, J., Gendron, Y., \& Guénin-Paracini, H. 2014. The construction of the risky individual and vigilant organization: A genealogy of the Fraud Triangle. Accounting, Organizations and Society, 39: 170-194.

Naumovska, I., Wernicke, G., \& Zajac, E. 2017. Unsettling settling-up? Corporate fraud and heterogeneity in the reputational penalties to directors. Academy of Management Proceedings, 2017: 17366.

*Ndofor, H. A., Wesley, C., \& Priem, R. L. 2015. Providing CEOs with opportunities to cheat: The effects of complexity-based information asymmetries on financial reporting fraud. Journal of Management, 41: 1774-1797.

*O’Connor, J. P., Priem, R. L., Coombs, J. E., \& Gilley, K. M. 2006. Do CEO stock options prevent or promote fraudulent financial reporting? Academy of Management Journal, 49: 483-500.

Oliver, A., Krause, R., Busenbark, J. R., \& Kalm, M. 2018. BS in the boardroom: Benevolent sexism and board chair orientations. Strategic Management Journal, 39: 113-130.

*Palmer, D. A., \& Yenkey, C. B. 2013. An organizational analysis of performance enhancing drug use in the 2010 Tour de France. Academy of Management Proceedings, 2013: 12972.

Paruchuri, S., \& Misangyi, V. F. 2015. Investor perceptions of financial misconduct: The heterogeneous contamination of bystander firms. Academy of Management Journal, 58: 169-194.

*Patelli, L., \& Pedrini, M. 2015. Is tone at the top associated with financial reporting aggressiveness? Journal of Business Ethics, 126: 3-19.

*Peterburgsky, S. 2012. In search of responsible CEOs: The case of CEOs with non-profit experience. Journal of Business Research, 65: 1374-1383.

*Pfarrer, M. D., Smith, K. G., Bartol, K. M., Khanin, D. M., \& Zhang, X. 2008. Coming forward: The effects of social and regulatory forces on the voluntary restatement of earnings subsequent to wrongdoing. Organization Science, 19: 386-403.

*Pierce, L., \& Snyder, J. 2008. Ethical spillovers in firms: Evidence from vehicle emissions testing. Management Science, 54: 1891-1903.

*Pierce, L., \& Toffel, M. W. 2013. The role of organizational scope and governance in strengthening private monitoring. Organization Science, 24: 1558-1584.

*Pinto, J., Leana, C. R., \& Pil, F. K. 2008. Corrupt organizations or organizations of corrupt individuals? Two types of organization-level corruption. Academy of Management Review, 33: 685-709.

*Ramdani, D., \& van Witteloostuijn, A. 2012. The shareholder-manager relationship and its impact on the likelihood of firm bribery. Journal of Business Ethics, 108: 495-507.

*Rehg, M. T., Miceli, M. P., Near, J. P., \& Van Scotter, J. R. 2008. Antecedents and outcomes of retaliation against whistleblowers: Gender differences and power relationships. Organization Science, 19: 221-240.

Reid, E. M., \& Toffel, M. W. 2009. Responding to public and private politics: Corporate disclosure of climate change strategies. Strategic Management Journal, 30: 1157-1178.

*Rijsenbilt, A., \& Commandeur, H. 2013. Narcissus enters the courtroom: CEO narcissism and fraud. Journal of Business Ethics, 117: 413-429.

Rowe, W. G., Cannella, A. A., Rankin, D., \& Gorman, D. 2005. Leader succession and organizational performance: Integrating the common-sense, ritual scapegoating, and vicious-circle succession theories. Leadership Quarterly, 16: 197-219.

Sawers, K., Wright, A., \& Zamora, V. 2011. Does greater risk-bearing in stock option compensation reduce the influence of problem framing on managerial risk-taking behavior? Behavioral Research in Accounting, 23: 185-201.

Schnatterly, K. 2003. Increasing firm value through detection and prevention of white-collar crime. Strategic Management Journal, 24: 587-614.

*Shi, W., Connelly, B. L., \& Hoskisson, R. E. 2017. External corporate governance and financial fraud: Cognitive evaluation theory insights on agency theory prescriptions. Strategic Management Journal, 38: 1268-1286. 
*Shi, W., Connelly, B. L., \& Sanders, W. 2016. Buying bad behavior: Tournament incentives and securities class action lawsuits. Strategic Management Journal, 37: 1354-1378.

Short, J. 2009. The art of writing a review article. Journal of Management, 35: 1312-1317.

Simpson, S. S., \& Koper, C. S. 1997. The changing of the guard: Top management characteristics, organizational strain, and antitrust offending. Journal of Quantitative Criminology, 13: 373-404.

Simsek, Z., Heavey, C., \& Veiga, J. J. F. 2010. The impact of CEO core self-evaluation on the firm's entrepreneurial orientation. Strategic Management Journal, 31: 110-119.

*Smith-Crowe, K., Tenbrunsel, A. E., Chan-Serafin, S., Brief, A. P., Umphress, E. E., \& Joseph, J. 2015. The ethics "fix": When formal systems make a difference. Journal of Business Ethics, 131: 791-801.

*Smith-Crowe, K., \& Warren, D. E. 2014. The emotion-evoked collective corruption model: The role of emotion in the spread of corruption within organizations. Organization Science, 25: 1154-1171.

Sonenshein, S. 2014. How organizations foster the creative use of resources. Academy of Management Journal, 57: 814-848.

*Spencer, J., \& Gomez, C. 2011. MNEs and corruption: The impact of national institutions and subsidiary strategy. Strategic Management Journal, 32: 280-300.

Statman, M. 2007. Local ethics in a global world. Financial Analysts Journal, 63: 32-41.

*Stevens, G. W., Deuling, J. K., \& Armenakis, A. A. 2012. Successful psychopaths: Are they unethical decisionmakers and why? Journal of Business Ethics, 105: 139-149.

Sullivan, B. N., Haunschild, P., \& Page, K. 2007. Organizations non gratae? The impact of unethical corporate acts on interorganizational networks. Organization Science, 18: 55-70.

Sykes, G. M., \& Matza, D. 1957. Techniques of neutralization: A theory of delinquency. American Sociological Review, 22: 664-670.

*Tang, T. L. P., \& Sutarso, T. 2013. Falling or not falling into temptation? Multiple faces of temptation, monetary intelligence, and unethical intentions across gender. Journal of Business Ethics, 116: 529-552.

Tang, Y., Li, J., \& Yang, H. 2015. What I see, what I do: How executive hubris affects firm innovation. Journal of Management, 41: 1698-1723.

Tihanyi, L., Graffin, S., \& George, G. 2014. Rethinking governance in management research. Academy of Management Journal, 57: 1535-1543.

Trahms, C. A., Ndofor, H. A., \& Sirmon, D. G. 2013. Organizational decline and turnaround: A review and agenda for future research. Journal of Management, 39: 1277-1307.

Trompeter, G. M., Carpenter, T. D., Desai, N., Jones, K. L., \& Riley, R. A., Jr. 2013. A synthesis of fraud-related research. Auditing: A Journal of Practice \& Theory, 32: 287-321.

*Troy, C., Smith, K. G., \& Domino, M. A. 2011. CEO demographics and accounting fraud: Who is more likely to rationalize illegal acts? Strategic Organization, 9: 259-282.

Vadera, A. K., \& Aguilera, R. V. 2015. The evolution of vocabularies and its relation to investigation of white-collar crimes: An institutional work perspective. Journal of Business Ethics, 128: 21-38.

Vadera, A. K., Aguilera, R. V., \& Caza, B. B. 2009. Making sense of whistle-blowing's antecedents: Learning from research on identity and ethics programs. Business Ethics Quarterly, 19: 553-586.

*Vadera, A. K., \& Pratt, M. G. 2013. Love, hate, ambivalence, or indifference? A conceptual examination of workplace crimes and organizational identification. Organization Science, 24: 172-188.

*Weber, J. 2010. Assessing the "tone at the top": The moral reasoning of CEOs in the automobile industry. Journal of Business Ethics, 92: 167-182.

Welsh, D. T., \& Ordóñez, L. D. 2014. Conscience without cognition: The effects of subconscious priming on ethical behavior. Academy of Management Journal, 57: 723-742.

Westphal, J. D., \& Bednar, M. K. 2005. Pluralistic ignorance in corporate boards and firms' strategic persistence in response to low firm performance. Administrative Science Quarterly, 50: 262-298.

Westphal, J. D., \& Zajac, E. J. 2013. A behavioral theory of corporate governance: Explicating the mechanisms of socially situated and socially constituted agency. Academy of Management Annals, 7: 607-661.

Whetten, D. A. 1980. Organizational decline: A neglected topic in organizational science. Academy of Management Review, 5: 577-588.

Wiersema, M. F., \& Zhang, Y. A. 2013. Executive turnover in the stock option backdating wave: The impact of social context. Strategic Management Journal, 34: 590-609.

Wiesenfeld, B. M., Wurthmann, K. A., \& Hambrick, D. C. 2008. The stigmatization and devaluation of elites associated with corporate failures: A process model. Academy of Management Review, 33: 231-251. 
Withers, M. C., \& Fitza, M. A. 2017. Do board chairs matter? The influence of board chairs on firm performance. Strategic Management Journal, 38: 1343-1355.

Wowak, A. J., Mannor, M. J., \& Wowak, K. D. 2015. Throwing caution to the wind: The effect of CEO stock option pay on the incidence of product safety problems. Strategic Management Journal, 36: 1082-1092.

Wurthmann, K. A. 2014. Service on a stigmatized board, social capital, and change in number of directorships. Journal of Management Studies, 51: 814-841.

*Yiu, D. W., Xu, Y., \& Wan, W. P. 2014. The deterrence effects of vicarious punishments on corporate financial fraud. Organization Science, 25: 1549-1571.

*Zahra, S. A., Priem, R. L., \& Rasheed, A. A. 2005. The antecedents and consequences of top management fraud. Journal of Management, 31: 803-828.

*Zavyalova, A., Pfarrer, M. D., Reger, R. K., \& Shapiro, D. L. 2012. Managing the message: The effects of firm actions and industry spillovers on media coverage following wrongdoing. Academy of Management Journal, 55: 1079-1101.

Zhang, X., Bartol, K. M., Smith, K. G., Pfarrer, M. D., \& Khanin, D. M. 2008. CEOs on the edge: Earnings manipulation and stock-based incentive misalignment. Academy of Management Journal, 51: 241-258.

Zhong, C. B. 2011. The ethical dangers of deliberative decision making. Administrative Science Quarterly, 56: 1-25.

Zyglidopoulos, S. C., Fleming, P. J., \& Rothenberg, S. 2009. Rationalization, overcompensation and the escalation of corruption in organizations. Journal of Business Ethics, 84: 65-73. 